\title{
THE EFFECT OF SPIN-OFF POLICY ON FINANCING GROWTH IN INDONESIAN ISLAMIC BANKING INDUSTRY
}

\author{
M. Nur Rianto Al Arif \\ UIN Syarif Hidayatullah Jakarta \\ (nur.rianto@uinjkt.ac.id)
}

\begin{abstract}
The purpose of this paper is to analyze the relationship between spin-off policy on the financing growth of Islamic banking industry in Indonesia. This research used panel regression with fixed effect. The variable used in this paper is dummy variabel of spin-off, and also included the internal factor of industry such as third party fund, and efficiency ratio (measured by BOPO). Besides the internal factor, this research also included the external factor such as inflation rate, economic growth rate, and interest rate from conventional banking. The result shows that only third part funds and interest rate had an impact on the financing growth in spin-off banks. The spin-off policy doesn't have an impact on the financing growth in spin-off banks
\end{abstract}

Tujuan dari penulisan artikel ini ialah untuk menganalisis keterkaitan antara kebijakan pemisahan terhadap pertumbuhan pembiayaan pada industri perbankan syariah di Indonesia. Penelitian ini menggunakan teknik regresi panel dengan model efek tetap. Variabel yang dipergunakan dalam artikel ini ialah variabel dummy pemisahan, serta memasukkan pula faktor internal seperti dana pihak ketiga dan rasio efisiensi yang diukur dari BOPO. Selain itu dimasukkan pula faktor eksternal seperti tingkat inflasi, tingkat pertumbuhan ekonomi, dan tingkat suku bunga dari bank konvensional. Hasil yang ada menunjukkan bahwa hanya dana pihak ketiga dan tingkat bunga yang memiliki pengaruh terhadap pertumbuhan pembiayaan di bank syariah yang pisah. Kebijakan pemisahan tidak memiliki pengaruh terhadap pertumbuhan pembiayaan di bank syariah yang pisah.

Keywords: spin-off, financing, panel regression 


\section{A. Introduction}

July 16, 2008, has passed Law No. 21 of 2008 concerning Islamic Banking. With the passing of this law provides the legal basis and the national Islamic banking industry is expected to encourage the development of Islamic banking industry for the better. One of the crucial issues in this legislation that can accelerate the development of Islamic banking in Indonesia is related to the separation (spin-off) Islamic business units both voluntary and mandatory if the asset Islamic business unit has reached $50 \%$ of the parent bank's assets or 15 years after the Act No. 21 of 2008 applied.

Islamic banking has grown rapidly in Indonesia. This is shown by the development of third-party funds, financing and distribution of assets in the Islamic banking industry from the years before the regulations regarding the spin-off and after the rule of the spin-off. Seen that from year to year, that an increase in either of assets, third-party funds, and the distribution of financing in Islamic banks.

Table 1. The Growth of Third Party Fund, Financing and Asset (Billion rupiah)

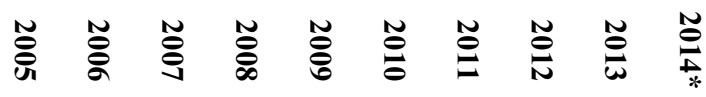

\begin{tabular}{|c|c|c|c|c|c|c|c|c|c|c|}
\hline Fundraising & $\begin{array}{l}\vec{u} \\
\dot{\omega} \\
\stackrel{\infty}{N}\end{array}$ & $\begin{array}{l}\text { Oे } \\
\dot{\vec{N}}\end{array}$ & $\begin{array}{l}\infty \\
\stackrel{N}{O} \\
\stackrel{O}{=}\end{array}$ & $\begin{array}{l}\omega \\
\stackrel{\omega}{\omega} \\
\dot{\omega} \\
\tilde{N}\end{array}$ & 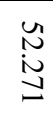 & $\begin{array}{l}\vec{\alpha} \\
\dot{d}\end{array}$ & $\begin{array}{l}\bar{n} \\
\dot{t}\end{array}$ & & & 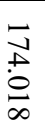 \\
\hline Financing & $\begin{array}{l}\underset{\cup}{\tilde{\omega}} \\
\stackrel{\omega}{\omega}\end{array}$ & $\begin{array}{l}\stackrel{N}{O} \\
\stackrel{+}{E}\end{array}$ & 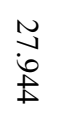 & $\begin{array}{l}\omega \\
\infty \\
\dot{\phi} \\
\stackrel{+}{\circ}\end{array}$ & $\begin{array}{l}t \\
\text { aे } \\
\infty \\
\infty \\
\infty\end{array}$ & $\underset{\infty}{\infty}$ & 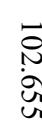 & & & 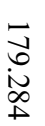 \\
\hline Asset & $\begin{array}{l}\tilde{O} \\
\infty \\
\dot{0} \\
0\end{array}$ & $\underset{\stackrel{N}{N}}{\stackrel{N}{N}}$ & $\begin{array}{l}\mathscr{\omega}_{u} \\
\stackrel{u}{u}\end{array}$ & $\begin{array}{l}\vec{t} \\
\dot{\dot{u}} \\
\text { ü }\end{array}$ & $\begin{array}{l}\text { के } \\
\dot{8}\end{array}$ & $\begin{array}{l}\stackrel{0}{u} \\
\underset{\sigma}{0}\end{array}$ & & & & 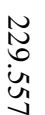 \\
\hline
\end{tabular}

Source: Islamic banking statistics, Bank of Indonesia

Total funding from year to year showed an increasing trend. However, from the composition of financing provided shows that the largest financing agreement was extended on murabaha contract is equal to $60 \%$ of the total financing. Though supposedly financing contract in Islamic banks must be located in profit-sharing contracts (such as mudaraba and Musharaka). Ones of the things that differentiates between conventional banking Islamic banking in addition to associated with interest is whether Islamic banking is really able to 
move the real sector which in this case can be seen from its influence on the level of investment.

\section{Table 2. Financing Composition in Islamic Banking (Billion rupiah)}

\begin{tabular}{|c|c|c|c|c|c|c|c|}
\hline Contract & 气్̊̆ & 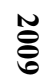 & $\stackrel{\tilde{O}}{\theta}$ & $\stackrel{N}{\Xi}$ & $\stackrel{\widetilde{N}}{\stackrel{N}{N}}$ & $\stackrel{\widetilde{S}}{\omega}$ & $\stackrel{N}{\Xi}$ \\
\hline Mudharabah & 宂 & i্ & $\begin{array}{l}\infty \\
\dot{\omega}\end{array}$ & $\stackrel{\text { D }}{\underset{\text { N }}{\text { N }}}$ & $\begin{array}{l}\bar{N} \\
\stackrel{\tilde{N}}{\omega}\end{array}$ & $\begin{array}{l}\bar{\omega} \\
\dot{\alpha} \\
\dot{\phi}\end{array}$ & $\begin{array}{l}w \\
\dot{\omega} \\
\dot{0}\end{array}$ \\
\hline Musyarakah & $\stackrel{\vec{E}}{\Xi}$ & $\begin{array}{l}\overrightarrow{0} \\
\stackrel{+}{N}\end{array}$ & $\begin{array}{l}\overrightarrow{+} \\
\dot{\vec{D}} \\
\dot{+}\end{array}$ & $\begin{array}{l}\vec{\infty} \\
\dot{8} \\
8\end{array}$ & 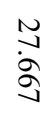 & 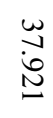 & $\begin{array}{l}\stackrel{t}{i} \\
\dot{\infty} \\
\mathscr{d}\end{array}$ \\
\hline Murabahah & \begin{tabular}{l}
$N$ \\
$N$ \\
$\stackrel{N}{*}$ \\
\multirow{2}{*}{}
\end{tabular} & $\begin{array}{l}\stackrel{N}{\sim} \\
\stackrel{N}{N}\end{array}$ & $\begin{array}{l}\text { w } \\
\dot{\ddot{\omega}} \\
\infty\end{array}$ & 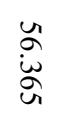 & $\begin{array}{l}\infty \\
\infty \\
\dot{\varnothing} \\
\varnothing\end{array}$ & $\begin{array}{l}\overrightarrow{.} \\
\overrightarrow{+} \\
\stackrel{+}{+} \\
+\end{array}$ & $\begin{array}{l}\bar{N} \\
\text { N } \\
\infty\end{array}$ \\
\hline Istishna & 亗 & 志 & $\stackrel{\omega}{ \pm}$ & Nू & $\vec{J}$ & $\underset{\infty}{\mathbb{\infty}}$ & $\underset{\infty}{u}$ \\
\hline Ijarah & 宓 & $\overrightarrow{\dot{\omega}}$ & $\begin{array}{l}\underset{\omega}{\sim} \\
\stackrel{ \pm}{ \pm}\end{array}$ & $\begin{array}{l}w \\
\dot{w} \\
\underset{\sigma}{\infty}\end{array}$ & $\begin{array}{l}\vec{\omega} \\
\dot{\omega} \\
\dot{\omega}\end{array}$ & $\begin{array}{l}\overrightarrow{\tilde{N}} \\
\dot{\mathbb{E}}\end{array}$ & $\underset{i}{\vec{\omega}}$ \\
\hline Qardh & 离 & 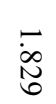 & $\stackrel{\vec{\omega}}{\omega}$ & $\begin{array}{l}\bar{N} \\
\stackrel{0}{u} \\
\text { U. }\end{array}$ & $\begin{array}{l}\bar{N} \\
\dot{0}\end{array}$ & $\begin{array}{l}\stackrel{0}{+} \\
\stackrel{+}{+}\end{array}$ & $\stackrel{\infty}{0}$ \\
\hline
\end{tabular}

\section{Total}

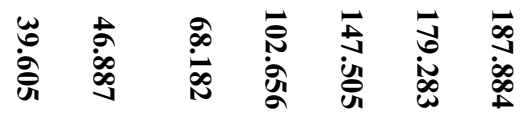

Source: Islamic banking statistics, Bank of Indonesia

According Tübke ${ }^{1}$ there are several factors that affect the separation process (spin-off). First, the factors associated with the business activity, the

1 Alexander Tubke. Success Factors of Corporate Spin-Offs. (New York: Springer, 2004), p. 30 
first factor is related to the size of the company and the business sector differences between the parent company to its subsidiaries. If the first factor is associated with the Islamic business unit can be positioned as a conventional bank subsidiaries and parent company. Second, the factors associated with the organization and management of the company. Third, factors associated with relationships and support. There are three patterns of relationships that may be created between the parent company with subsidiaries which perform the separation, namely the relationship market (market-Relatedness), the relationship of the product (product Relatedness), and the relationship of technology (technology-Relatedness). Fourth, transfer factor or transfer such transfer of experience from the parent company to its subsidiaries. Fifth, factors associated with motivation. Sixth, the factors associated with the business environment in the form of the characteristics of the regional business environment and legal framework

Nasuha conducted a study related to differences in the performance of Islamic business unit who decided to split (BNI Sharia, BRI Sharia, BJB Sharia, BSB, and Bank Victoria Sharia) one year before and one year after the spin-off by using the Wilcoxon analysis Match Pairs test which is a refinement of the test mark (sign test). The results obtained are of the nine variables, assets, financing, deposits, net profit, CAR, NPF, FDR, ROA, and ROE were tested with Wilcoxon Signed Ranks Test method shows that the performance difference between before and after the spin-off occurred on 3 variables, i.e. assets, financing, and Third Party Fund (TPF). It can be seen from the significant value that is less than $\alpha$. That is, there is the effect of the spin-off activity before and after. While on the other variables, CAR, FDR, ROA, and ROE showed no difference in performance between 1 year before and 1 year after the spin-off, with a significance value greater than $\alpha$. This might be due to the spin-off is still practiced in the new Islamic banking industry, so the testing period was short.

This research aims to analyze the impact of spin-off policy on the financing growth in Islamic banking industry. This research will show whether the Islamic commercial bank resulted from spin-off can increase the financing after the spin-off decision. The finding of this research will contribute the spinoff practice on Islamic banking industry in Indonesia.

Differentiation this research over previous researches is as follows. First, this research uses the panel data from four Islamic commercial bank resulted from spin-off. Second, the study discusses about the spin-off of Islamic banking is still very limited, so this research will make a significant contribution to the development of the theory of spin-offs of Islamic banking. Third, this research analyzes does the spin-off policy had an impact on financing growth of Islamic banking industry. 
To achieve the goal of this research analyzing the influence of spin-off policy on the financing growth of Indonesian Islamic banking, regression with panel data analysis is used.The data used are quarterly data from 2005 to 2014 , by including four Islamic banks spinoff (such as BNI Syariah, BRI Syariah, Bukopin Syariah, and BJB Syariah). Statistical data comes from Bank Indonesia Islamic banking and Islamic commercial bank's financial statements results of the spin-off which is the object of research.

The mathematical equation proposed in this research is:

$Y_{\text {it }}=\alpha+\beta_{1} D_{\text {it }}+\beta_{2}$ Fund $_{\text {it }}+\beta_{3}$ Eff $_{\text {it }}+\beta_{4}$ Inflation $_{t}+\beta_{5}$ Interest $_{t}$ $+\beta_{6}$ Growth $_{\mathrm{t}}+\varepsilon_{\mathrm{it}}$

where:

$Y_{i t}=$ financing;

$D_{i t}=$ Dummy variable for spin-off

Which is: 0 before spin-off, 1 after spin-off

Fund $_{\text {it }}=$ third party fund

Eff $_{\text {it }}=$ operational efficiency ratio

Inflation $_{\mathrm{t}}=$ inflation rate

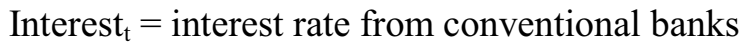

Growth $_{\mathrm{t}}=$ economic growth of Indonesia

To estimate the parameter of the model using panel data regression, there are several techniques that can be used, such as: First, ordinary least square. Second, fixed effect model. Third, random effect model. On these research is using panel regression with fixed effect model, because we assume that the intercept is not constant.

\section{B. Literature Review}

Until now there has not been a lot of theories or research found associated with the spin-off in Islamic banks. This is due to the spin-off of the new Islamic banks only first practiced in Indonesia. Therefore, theories or models of the spin-off will be done with the model of spin-offs are applied to industry in general.

According Elfring and Foss ${ }^{2}$ there are two types of spin-off, namely: first, in terms of its parent company, in which the parent company for some reason is not able or not able to exploit the opportunities that come by. The

${ }^{2}$ T. Elfring, T. \& N.J. Foss. Corporate Renewal Through Internal Venturing and Spin-offs: Perspectives from Organizational Economics. (Working Paper 97-7. Department of Industrial Economics and Strategy Copenhagen Business School, 1997), p. $8-10$ 
second type is related to organizational units as an individual, in this second type is the type most widely performed, in which the subsidiary is not the same as its parent company. This second type contained in the spin-off of the Islamic banking units in conventional banks in Indonesia.

Klepper and Thompson ${ }^{3}$ said that there are three themes of spin-off. First, many of the spinoffs were based on technical ideas that originated within their parent firm but the parent declined to support aggressively or at all. Second, a number of the spinoffs were based on disagreements over the strategic direction of the parent firm and/or fundamental management practices related to the organization of the parents and its method of rewarding high-level employees. Third, founders of the spinoffs were often top managers, including founders and CEOs, and/or top scientist and engineers.

Chemmanur and $\mathrm{Yan}^{4}$ developed a new rationale for corporate spinoffs, and for the performance and value improvements following them. The firm has two divisions, and current management has differing abilities for managing these two divisions. Spin-offs can enhance firm management. In addition, on their analysis demonstrates that in addition to positive abnormal stock-price return on the announcement day, spin-offs also lead to positive long-term abnormal stock returns (on average) for parent spin-offs combination reporting subsequent takeover activity.

Bchini $^{5}$ assess the opportunity of the use of spin-off to ensure both growth and entrepreneurial success in the Tunisian context. This paper identified three forms of spin-off in Tunisia such as the project spin-off, the outsourcing spin-off, and extrapreneurship. Each type leads to growth and entrepreneurial success, but the most successful form is extrapreneurship.

$\mathrm{Ch} \mathrm{u}^{6}$ done the study that bridges a gap in current literature by providing empirical evidence of factors affecting the performance of non-academic spinoffs originating from the Acer Group in Taiwan. The analytical result obtained by this study highlight two issues. First, spin-off performance is likely to be enhanced if its operations are linked to those of the parent. Second, a spin-off performs better during its initial stages if it is an internal venture spun out from

${ }^{3}$ S. Klepper, S. P. Thompson. Disaggrements and Intra-Industry Spinoffs. (International Journal of Industrial Organization, Elsevier, vol. 28(5), September 2010), p. 526-538.

${ }^{4}$ T.J. Chemmanur, \& A.Yan. A Theory of Corporate Spin-offs. (Journal of Financial Economics, Elsevier, Vol. 72, Issue 2, May 2004), p. 259-290.

${ }^{5}$ Bchini, B. Spin-off: Factor of Growth and Entrepreneurial Success: The Example of Tunisia. (International Journal of Business and Social Science, Vol. 3, No. 12, June 2012), p. 65-75.

${ }^{6}$ Chu, P.Y., et. al. Spin-off Strategies and Performance: A case study of Taiwan's Acer Group. (Asian Business and Management, 2010, Vol. 9, 1), p. 101-125 
the parent company with its technology researched and developed within the parent.

Nasuha $^{7}$ done the research about the performance difference on Islamic banking unit that decided to spin-off, such as BNI Shariah, BRI Shariah, BJB Shariah, BSB and Victoria Shariah. The research is done by Wilcoxon Match Pairs test that saw the performance between pre and post spin-off decision on Islamic banking units. The result shown that only asset, financing and third party funds that shown a difference between before and after spin-off policies on that five banks. Otherwise for other variables such as CAR, FDR, ROA and ROE shown that there were no difference on CAR, FDR, ROA and ROE in Islamic banks.

\section{Result and Dicussion}

The estimation result from panel regression with fixed effect shows that the variables affect the financing on Islamic banks result from spin-off are dummy third party fund and interest rate. Intercept give a positive and significant result, these things shows that if all variables on this model are assumed zero, the Islamic banks will still distributed the financing as an intercept coefficient value. Significant results in third party funds variable indicates that the higher third-party funds that can be done by Islamic banks, it will increase the amount of the finance portfolio of Islamic banks.

Interest rates variable have a positive influence on the growth of the finance portfolio in Islamic banks. This happens because if the interest rate on conventional bank financing is higher than the margin of financing of Islamic banks, there will be a transfer of customer financing from conventional banks to Islamic banks.

\section{Table 3. The Estimation Result}

Dependent Variable: PEMBIAYAAN

Method: Panel EGLS (Cross-section weights)

Periods included: 39

Cross-sections included: 4

Total panel (balanced) observations: 156

Linear estimation after one-step weighting matrix

\begin{tabular}{ccccc}
\hline \hline Variable & Coefficient & Std. Error & t-Statistic & Prob. \\
\hline \hline C & 1466447. & 534324.8 & 2.744486 & 0.0068 \\
D_SPINOFF & 44730.50 & 98110.44 & 0.455920 & 0.6491
\end{tabular}

${ }^{7}$ Amalia Nasuha. The Impact of Spin-off Policy on Islamic Bank Performance. (Al-Iqtishad Journal, Vol. IV, No. 2, July 2012), p. 241-258. 


\begin{tabular}{cllll} 
FUND & 1.154882 & 0.013208 & 87.43722 & 0.0000 \\
EFF & 724.3612 & 1640.595 & 0.441523 & 0.6595 \\
INFL & 668968.4 & 947560.8 & 0.705990 & 0.4813 \\
INT & 197468.5 & 95837.19 & 2.060458 & 0.0411 \\
GROWTH & 58416.65 & 52721.55 & 1.108022 & 0.2697 \\
\hline \hline
\end{tabular}

Effects Specification

Cross-section fixed (dummy variables)

Weighted Statistics

\begin{tabular}{lllr}
\hline \hline R-squared & 0.993636 & Mean dependent var & 7030817. \\
Adjusted R-squared & 0.993244 & S.D. dependent var & 10682925 \\
S.E. of regression & 858333.4 & Sum squared resid & $1.08 \mathrm{E}+14$ \\
F-statistic & 2532.888 & Durbin-Watson stat & 1.682320 \\
Prob(F-statistic) & 0.000000 & & \\
\hline
\end{tabular}

Unweighted Statistics

\begin{tabular}{lcll}
\hline \hline R-squared & 0.960695 & Mean dependent var & 3753012. \\
Sum squared resid & $1.39 \mathrm{E}+14$ & Durbin-Watson stat & 2.876573 \\
\hline \hline
\end{tabular}

The value of determination coefficient shows by the value of $\mathrm{R}^{2} 0.9936$ and the value of adjusted $\mathrm{R}^{2} 0.9932$. This result shows that fixed effect model can explain the model in about $99.32 \%$ and $0.68 \%$ is explained by other variables outside the model. The value of $F$ statistics show significant results, so that it can be said that simultaneously all variables affect the dependent variable of financing in Islamic banks. Further test is done to see whether the use of fixed effects model has the added value compared to the pooled OLS. In Table 5 , the value of the $F$ statistic indicates a value of 25.225 with a $p$ value of 0.00 . Thus it can be said that the fixed effects models provide significant added value compared with the pooled OLS models.

Table 4. Likelihood Ratio Test

Redundant Fixed Effects Tests

Equation: Untitled

Test cross-section fixed effects

\begin{tabular}{llll}
\hline \hline Effects Test & Statistic & d.f. & Prob. \\
\hline \hline
\end{tabular}


Cross-section fixed effects test equation:

Dependent Variable: PEMBIAYAAN

Method: Panel EGLS (Cross-section weights)

Periods included: 39

Cross-sections included: 4

Total panel (balanced) observations: 156

Use pre-specified GLS weights

\begin{tabular}{crrrr}
\hline \hline Variable & Coefficient & Std. Error & t-Statistic & Prob. \\
\hline \hline C & 736333.2 & 602614.8 & 1.221897 & 0.2237 \\
D_SPINOFF & -183956.5 & 115191.7 & -1.596960 & 0.1124 \\
FUND & 1.205434 & 0.012755 & 94.50576 & 0.0000 \\
EFF & 1175.511 & 1843.276 & 0.637729 & 0.5246 \\
INF & 712682.9 & 1155203. & 0.616933 & 0.5382 \\
INT & -18732.16 & 110302.0 & -0.169826 & 0.8654 \\
GROWTH & -100279.0 & 63727.92 & -1.573550 & 0.1177 \\
\hline \hline & Weighted Statistics & & \\
\hline \hline R-squared & 0.990338 & Mean dependent var & 7030817. \\
Adjusted R-squared & 0.989948 & S.D. dependent var & 10682925 \\
S.E. of regression & 1046939. & Sum squared resid & $1.63 \mathrm{E}+14$ \\
F-statistic & 2545.259 & Durbin-Watson stat & 1.171774 \\
Prob(F-statistic) & 0.000000 & & & \\
\hline \hline
\end{tabular}

Unweighted Statistics

\begin{tabular}{lcll}
\hline \hline R-squared & 0.955376 & Mean dependent var & 3753012. \\
Sum squared resid & $1.58 \mathrm{E}+14$ & Durbin-Watson stat & 2.623773 \\
\hline
\end{tabular}

The results obtained in this study indicate that factors influencing the amount of financing are third-party funds and the interest rate. This result is similar with Asy'ari $^{8}$, his research shown that the factors that affect on financing growth are third party fund and interest rate. Ambarwati ${ }^{9}$ also found

${ }^{8}$ Mohammad Hasyim Asy'ari. The Factors That Influence Islamic Bank's Financing. (Unpublished Thesis). (Depok: Universitas Indonesia, 2009)

9 Septiana Ambarwati. The Factors That Influence the Murabahah and Mudharabah Financing on Indonesian Islamic Commercial Banking. (Unpublished thesis). (Depok: Universitas Indonesia, 2011), 
that the credit interest rate on conventional banking had a significant influence on the financing growth on Islamic banking. Besides the interest rate, the other variable that also had an affect are non performing finance and SWBI bonuses.

Adebola et.al ${ }^{10}$ investigates the impact of conventional bank interest rate on the volume of financing of Islamic banks in Malaysia. His study shows that interest rate significantly affects Islamic banks financing in Malaysia. This is taken to mean that Islamic banks financing is complementary rather than substitute to conventional banks financing. Hence, it is recommended that Islamic banks in Malaysia should accommodate more profit and loss products in order to be more interest-free.

According to the estimation result shows that the spin-off policy doesn't have an impact on financing growth in Islamic banks resulted from spin-off. This implies that the spin-off policy is contained in the Act No. 21 of 2008 related to the article governing the separation is still need an improvement to accelerate the financing growth of Islamic banks resulted from spin-off.

These findings are inconsistent with that made by Al Arif ${ }^{11}$ that seeks to look at the effect of the spin-off policy on the growth of Islamic banking industry in Indonesia, which one of the purposes is to analyze the impact of spin-off policy on financing growth in Indonesian Islamic banking industry. In a previous study was using the independent variable in the form of a dummy variable separation, the level of financing problems (NPF), the value of the efficiency ratio (ROA), and the level of profitability (ROA). The results showed that all independent variables have a significant impact on financing growth on the Islamic banking industry in Indonesia.

Different results were obtained by Nasuha, which conducts research related to differences in the performance of Islamic business unit who decided to split (BNI Syariah, BRI Syariah, BJB Sharia, BSB, and Bank Victoria Sharia) one year before and one year after spin off by using the Wilcoxon Match Pairs test. The Wilcoxon Test shows that the performance difference between before and after the spin-off occurred on 3 variables, i.e. assets, financing, and Third Party Fund (TPF).

There are several arguments to explain why the spin-off policy doesn't have an impact on financing growth in Islamic banks resulted from spin-off. First, the operational cost of Islamic bank resulted from spin-off is higher than operational income, especially in earlier period of spin-off the operational efficiency values (BOPO) is very high. Therefore, the Islamic bank resulted

${ }^{10}$ Solarin Sakiru Adebola, , et.al. The Impact of Macroeconomic Variables on Islamic Banks Financing in Malaysia. (Research Journal of Finance and Accounting, Vol. 2, No. 4, 2011), p. 22-32

${ }_{11}$ M. Nur Rianto Al Arif. The Spin-off Impact to of Indonesian Islamic Banking Industry Growth. Working Paper. (Jakarta: UIN Syarif Hidayatullah Jakarta, 2014) 
from spin-off will be more careful in order not to add finance portfolio operating expenses. Second, Islamic banks resulted from spinoff still doing internal consolidation after the spin-off. Third, the Islamic banking network limitation, this is show on table 6 .

Table 6. The Islamic bank network

\begin{tabular}{lccc}
\hline \multicolumn{1}{c}{ Bank } & $\begin{array}{c}\text { Branch } \\
\text { Office }\end{array}$ & $\begin{array}{c}\text { Sub Branch } \\
\text { office }\end{array}$ & Cash Office \\
\hline BNI Sharia & 64 & 159 & 17 \\
BRI Sharia & 51 & 196 & 7 \\
BJB Sharia & 9 & 56 & 1 \\
Bukopin Sharia & 12 & 8 & 5 \\
Victoria Sharia & 8 & 11 & - \\
Panin Sharia & 7 & 5 & - \\
BCA Sharia & 8 & 6 & - \\
Maybank Sharia Indonesia & 1 & - & - \\
\hline
\end{tabular}

Source: Islamic banking statistics, Financial Service Authority

\section{Conclusion}

The estimation results to see the effect of spin-off policy on the financing growth in Islamic banks show that the spin-off dummy variable has no effect on the financing growth. Variables that influence in affecting the financing growth of Islamic commercial bank that result from spin-off on this study are third party funds and interest rate. This suggests that the higher thirdparty funds, the higher the amount of the financing of Islamic banks.

There are several arguments to explain why the spin-off policy doesn't have an impact on financing growth in Islamic banks resulted from spin-off. First, the operational cost of Islamic bank resulted from spin-off is higher than operational income, especially in earlier period of spin-off the operational efficiency values (BOPO) is very high. Therefore, the Islamic bank resulted from spin-off will be more careful in order not to add finance portfolio operating expenses. Second, Islamic banks resulted from spinoff still doing internal consolidation after the spin-off. Third, the Islamic banking network limitation. 


\section{REFERENCES}

Adebola, Solarin Sakiru, et.al. 2011. The Impact of Macroeconomic Variables on Islamic Banks Financing in Malaysia. Research Journal of Finance and Accounting, Vol. 2, No. 4.

Al Arif, M. Nur Rianto. 2014. The Spin-off Impact to of Indonesian Islamic Banking Industry Growth. Working Paper. Jakarta: UIN Syarif Hidayatullah Jakarta.

Ambarwati, Septiana. 2011. The Factors That Influence the Murabahah and Mudharabah Financing on Indonesian Islamic Commercial Banking. (Unpublished Thesis). Depok: Universitas Indonesia.

Asy'ari, Mohammad Hasyim. 2009. The Factors That Influence Islamic Bank's Financing. (Unpublished Thesis). Depok: Universitas Indonesia.

Bchini, B. 2012. Spin-off: Factor of Growth and Entrepreneurial Success: The Example of Tunisia. International Journal of Business and Social Science, Vol. 3, No. 12, June.

Chemmanur, T.J. \& A.Yan. 2004. A Theory of Corporate Spin-offs. Journal of Financial Economics, Elsevier, Vol. 72, Issue 2, May.

Chu, P.Y., et. al. 2010. Spin-off Strategies and Performance: A case study of Taiwan's Acer Group. Asian Business and Management, 2010, Vol. 9, 1.

Elfring, T. \& N.J. Foss. 1997. Corporate Renewal Through Internal Venturing and Spin-offs: Perspectives from Organizational Economics. Working Paper 97-7, Department of Industrial Economics and Strategy Copenhagen Business School.

Klepper, S. \& P. Thompson. 2010. Disaggrements and Intra-Industry Spinoffs. International Journal of Industrial Organization, Elsevier, vol. 28(5).

Nasuha, A. 2012. The Impact of Spin-off Policy on Islamic Bank Performance. Al-Iqtishad Journal, Vol. IV, No. 2.

Tubke, Alexander. Success Factors of Corporate Spin-Offs. New York: Springer. 